\title{
Nicolae Steinhardt - o contribuţie românească la autobiografia spirituală
}

\author{
Maxim MORARIU*
}

\begin{abstract}
In the Romanian space, the personality and work of Fr. Nicolae Steinhardt are surely very important. Among his notable works that be surely mentioned: The diary of happiness (Jurnalul fericirii). Published and re-published in several editions and translated in different languages, it represents not only a testimony regarding the prison or the repressive regime in this country, but also a work with important literary, philological, philosophical, historical and theological relevance. In discontinuously marks,
\end{abstract} sometimes accompanied by landmarks of space and times and other times not, he presents here the experience of prison together with other experiences, linking the facts lived with important literary works that determine him to have a certain perception on them, or with the mystical effect that they have. In the centre of his notes is the event of baptism (because Steinhardt is a Jew converted to Orthodoxy in prison and later, after the release, he becomes a monk in Rohia Monastery, in Maramureş, North Romania) and its spiritual consequences. Thanks to those aspects, his notes, although cannot be subsumed to the genre of the spiritual autobiography but remains a classic memorial work (a discontinuously diary), Steinhardt's diary is a work with important passages of spiritual autobiography. For this reason, we consider it a relevant Romanian contribution to the spiritual autobiography and we will try to emphasize inside this research the elements that brought us to this conclusion. Having important aspects of the aforementioned topic, it can be also an useful tool to create bridges with other Christian spiritualties, due to the fact that there

* Secretarul ştiinţific al Centrului de Studii „Ioan Lupaş” al Facultăţii de Teologie din Cluj-Napoca şi cercetător afiliat Institutului de Istorie Eclesiastică „Nicolae Bocşan" al Universităţii Clujene şi al Universităţii din Pretoria, Africa de Sud. 
can be found important works of the genre. For this reason, we will also present when needed the common points with autobiographies like the one of Teresa of Avila or the one of Dag Hammarskjöld.

Keywords: Rohia Monastery, communism, prison, repressive system, monks, conversion, mystical ecstasies'.

\section{Introducere}

În peisajul cultural şi cel spiritual românesc, părintele Nicolae Steinhardt ocupă un loc aparte. Predicile sale ${ }^{1}$, jurnalul ${ }^{2}$, dar şi celelalte texte ${ }^{3}$, se constituie în adevărate contribuţii la dezvoltarea culturii române, a literaturii, criticii literare sau a teologiei din acest spaţiu. Datorită lui, literatura dedicată peisajului carceral şi elementelor lui definitorii, dar şi efectului său duhovnicesc, s-a îmbogăţit nu doar sub aspect cantitativ, ci şi calitativ.

Desigur, dincolo de valenţele ei istoriografice, literare sau filosofice, Jurnalul fericirii, una dintre cele mai reprezentative opere ale autorului, asupra căreia intenţionăm să ne oprim în rândurile următoare, este important şi dintr-o altă perspectivă, respectiv datorită faptului că conţine dense pasaje de autobiografie spirituală. Genul în cauză este unul puţin valorificat în cercetarea

\footnotetext{
${ }^{1}$ Nicolae Steinhardt, Dăruind vei dobândi, Rohia, Edit. Mănăstirii Rohia, 2006.

${ }^{2}$ IDEM, Jurnalul fericirii, Rohia, Edit. Mănăstirii Rohia, 2005.

3 Precum: Nicolae STEINHARDT, Călătoria unui fiu risipitor - roman, ed. Ioan Pintea, Bucureşti, Edit. Adonai, 1995; IDEM, Critică la persoana I, ClujNapoca, Editura Dacia, 2001; IDEM, Eu însumi şi alţi câţiva (eseuri noi şi vechi), ed. Ioan Pintea, Cluj-Napoca, Edit. Dacia, 2001; IDEM, În genul...tinerilor, Bucureşti, Edit. Cultura Poporului, 1934; IDEM, Între viaţă şi cărţi, Bucureşti, Edit. Cartea Românească, 1976; IDEM, Ispita lecturii, ed. Ioan Pintea, Cluj-Napoca, Edit. Dacia, 2000; IDEM, Monologul polifonic, ed. Virgil Bulat, Cluj-Napoca, Edit. Dacia, 1991; IDEM, Cartea împărtăşirii, ed. Ion Vârtic, Cluj-Napoca, Edit. Biblioteca Apostrof, 1998; IDEM, Cuvinte de credinţă, ediţie definitivă îngrijită de Ioan Pintea, Bucureşti, Edit. Humanitas, 2006; IDEM, Drumul către isihie - inedite, eseuri, ed. Oana Cătina, ClujNapoca, Edit. Dacia, 1999; IDEM, Dumnezeu în care spui că nu crezi... Scrisori către Virgil Ierunca (1967-1983), ed. Monica Manu, Bucureşti, Edit. Humanitas, 2000; IDEM, Escale în timp şi spaţiu sau dincoace şi dincolo de texte, Bucureşti, Edit. Cartea Românească, 1987.
} 
contemporană, autorul prezentelor rânduri fiind unul dintre cei care s-au străduit să i se dedice în ultima vreme ${ }^{4}$. În plus, în spaţiul ortodox, din motive despre care am vorbit deja, a cunoscut o slabă receptare, comparativ cu cel catolic, de exemplu, unde opere precum cea a Terezei de Avila sau, mai recent, cele ale Papei Ioan Paul al II-lea, jurnalele maicii Tereza de Calcutta sau notele Mariei Faustina Kowalska, constituie deja stâlpi în înţelegerea lui, în timp ce, în cel protestant, în diferite spaţii şi contexte, s-a încercat chiar şi utilizarea lui cu scopuri prozelite.

4 Prin intermediul unor cercetări precum: Iuliu-Marius MORARIU, „An interdisciplinary genre in the Theological Literature: the spiritual autobiography and its landmarks for the Orthodox space", în Journal of Education, Culture and Society, VII (2018), no. 1, p. 145-149; IDEM, „The spiritual autobiography in the Eastern space in the second half of the XIXth and XXth centuries", in Astra Salvensis, III (2015), Supplement no 1 - „New Approaches in Contemporary Theology”, p. 166-174; IDEM, „Aspects of political theology in the spiritual autobiographies of the Orthodox space? New potential keys of lecture”, în Astra Salvensis, V (2017), no. 10, p. 128-133; IDEM, „Aspects of Applied Ethics in the Spiritual Autobiographies from the Orthodox Space in the 19thand 20th Centuries", în Camelia IGNĂTESCU, Antonio SANDU, Tomiţă Ciuler (eds.), Proceedings Volume: Rethinking Social Action. Core Values in Practice, Iași, Londra, Edit. Lumen, 2017, p. 548-557; IDEM, „Aspects of political theology in the spiritual autobiography of Dag Hammarskjöld", în HTS Teologiese Studies / Theological Studies, 74 (2018), no. 4, a4857, 2018, p. 1-5; IDEM, „Aspects of political theology in the spiritual autobiography of Saint John of Kronstadt (1829-1908)", în HTS Teologiese Studies / Theological Studies, 74 (2018), no. 4, 4993, 2018, p. 1-5; IDEM, „Educational aspects in the spiritual autobiography from the Orthodox space of the 19th and 20th centuries", în Ion AlbulesCU, Adriana-Denisa MANEA, Iuliu-Marius MorariU, Education, Religion, Family in Contemporary Society - Proceedings of the Conference, Saarbrucken, Lambert Academic Publishing, 2017, p. 113-123; Iuliu-Marius MORARIU / Ştefan JOSAN, „Elements of spiritual autobiography in the literary works of Virgil Gheorghiu", în Research and Science Today, 6 (2016), no. 1 (11), p. 83-88; Maxim MorariU, „Saint Silouane l'Athonite el l'autobiographie spirituelle dans l'Eglise Orthodoxe", în Presence d'En Calcat, 55 (2016), no. 1, p. 35-39; Maxim (Iuliu-Marius) MoRARIU, Autobiografia spirituală a lui Dag Hammarskjöld: o abordare teologică, Cluj-Napoca, Edit. Argonaut, 2016; IDEM, Repere ale autobiografiei spirituale din spaţiul ortodox in secolele XIX şi XX: Ioan de Kronstadt, Siluan Athonitul şi Nicolae Berdiaev, Iassy, Lumen Press, 2019. 
Dată fiind importanţa acestei opere, dar şi a faptului că se constituie într-un text important pentru genul teologico-literar pe care îl avem în vedere, am socotit necesar şi potrivit ca, în rândurile următoare, să ne oprim asupra lui.

\section{Nicolae Steinhardt - o contribuţie românească la autobiografia spirituală}

Aşa cum am menţionat deja, Jurnalul fericirii reprezintă cu certitudine, dacă nu cea mai faimoasă, atunci cel puţin una dintre cele mai importante şi mai reprezentative lucrări ale operei părintelui Steinhardt. O simplă răsfoire a catalogului unei biblioteci importante cum este cea universitară clujeană ${ }^{5}$, va reliefa curiosului existenţa a peste 10 ediţii şi a mai bine de 20 de traduceri în limbi străine a acestei operé .

Gândită ca lucrare memorialistică, scrisă şi rescrisă ulterior, dat fiind faptul că un prim manuscris a fost confiscat în urma percheziţ̧iilor efectuate de către Securitate, lucrarea a beneficiat nu doar de publicarea mai multor versiuni de manuscrise, ci şi de analize serioase, dedicate de specialişti din spaţiul istoriografiei, teologiei, literaturii, filosofiei şi chiar şi altor domenii. Pe baza textelor deja existente, dar şi a analizei proprii ce vizează valorificarea aspectelor de autobiografie spirituală, vom încerca să realizăm şi noi investigaţia de faţă.

Înainte de a începe, trebuie să menţionăm însă că, deşi conţine bogate pasaje de autobiografie spirituală, lucrarea monahului de la Rohia nu este totuşi o autobiografie spirituală propriu-zisă, ci un text memorialistic, ce conţine totuşi bogate

5 http://aleph.bcucluj.ro:8991/F/RMBU21RFQ3NFA4FB65SCLRAUAF3RDLX9K D3B4A4IS69PUX61DQ-09946? func $=$ short-jump\&jump=000101, accesat la data de: 29. 03. 2020.

6 În plus, au existat multe antreprize jurnalistice şi editoriale dedicate autorului şi operei pe care o avem în vedere. De exemplu, revista teologică Tabor de la Cluj, a dedicat numărul din luna iulie a anului 2009 lui Nicolae Steinhardt şi gândirii sale. Cf.: http://www.tabor-revista.ro/revistaCustom.php?revistaId=63, accesat la data de 30. 03. 2020. 
pasaje ce pot fi subsumate genului pe care îl avem în vedere. Reperele temporale şi spaţiale, ce-i drept, adesea vagi şi discontinue şi dorinţa autorului de a avea în centru aspectele istorice, fără a neglija însă latura spirituală şi transformarea interioară sau bogatele referinţe la literatura de specialitate, o fac să fie o preţioasă exponentă a textelor memorialistice dedicate spaţiului carceral, alături de alte lucrări similare ${ }^{7}$. Totuşi, spre deosebire de alţi autori, lipsiţi de vocaţie mistică sau care se străduiau să o ascundă, ea conţine totuşi şi elemente ce privesc acest spaţiu.

Un astfel de exemplu îl reprezintă descrierea unui vis ce are loc la Gherla în luna mai a anului 1963. În fapt, este vorba despre o viziune, descrisă în tuşe ce aduc izbitor cu cele ale Teresei de Avila $^{8}$. În mod cert, este vorba de un extaz mistic de felul celor

${ }^{7}$ Precum: Aspazia Oțel Petrescu, $\mathrm{Cu}$ Hristos în celulă, ediţia a 2-a, Bucureşti, Edit. Areopag, 2012; Nicole-Valery Grossu, Bénie sois-tu, prison, Paris, Les Editions du Plon, 1978; Lena Constante, Evadarea imposibilă - penitenciarul politic de femei, Miercurea Ciuc (1957-1961), ediţia a 2-a, Bucureşti, Edit. Florile Dalbe, 1996; IDEM, Evadarea tăcută - 3000 de zile singură in inchisorile din România, Bucureşti, Edit. Humanitas, 1992; Galina RĂDUlEANU, Repetitie la moarte, col. „Din spatele gratiilor”, Piteşti, Edit. Fundaţiei Sfinţii Închisorilor, 2013; Nichifor NICHIFOR, Memorii, vol. 2 „Pribeag în ţara mea - răspuns la actul meu de acuzare - mărturii din închisoare", ed. Alexandru Condeescu, Bucureşti, Edit. Muzeului Literaturii Române, 1996; Gheorghe CALCIU-Dumitreasa, Cuvinte vii - „, a sluji lui Hristos inseamnă suferinţă!", Bacău, Edit. Bonifaciu, 2009; *** Viaţa Părintelui Gheorghe Calciu după mărturiile sale şi ale altora, ediţie îngrijită la Mănăstirea Diaconeşti, Bucureşti, Edit. Christiana, 2007; Ioan IANOLIDE, Intoarcerea la Hristos - document pentru o lume nouă, ediţia a II-a, Bucureşti, Edit. Bonifaciu, 2012; IDEM, Deţinutul profet, ediţie îngrijită de Mănăstirea Diaconeşti, Bucureşti, Edit. Bonifaciu, 2009; Aurel State, Drumul crucii. Amintiri de pe front şi din Gulaguri, Piteşti, Bucureşti, Edit. Rost, Edit. Fundaţiei Închisorilor, 2013; Demostene ANDRONESCU, Reeducarea de la Aiud. $O$ radiografie memorialistică, Pitești, Edit. Manuscris, 2018; Valeriu ANANIA, Memorii, Iaşi, Edit. Polirom, 2008.

${ }^{8}$ Cf. Sfânta Tereza din Avila, Castelul interior, trad. Christian Tămaş, Iaşi, Edit. Ars Longa, 1995. A se vedea şi: Joseph Perez, Teresa de Avila y la España de su tiempo, Madrid, Mexico, Buenos Aires, San Juan, Santiago, Miami, Algaba Ediciones, 2007, p. 61-72, pentru o prezentare detaliată a viziunilor ei şi a modului în care acestea i-au schimbat viaţa. 
evocate de marii exponenţi ai tradiţiei isihaste. Iată ce consemnează cu privire la acest episod, monahul Nicolae:

„În noaptea următoare adorm frânt. Şi atunci, în noaptea aceea chiar, sunt dăruit cu un vis miraculos, o vedenie. Nu-L văd pe Domnul Hristos întrupat, ci numai o lumină uriaşă, albă şi strălucitoare - şi mă simt nespus de fericit. Lumina mă înconjoară din toate părţile, e o fericire totală şi înlătură totul; sunt scăldat în lumina orbitoare, plutesc în lumină, plutesc în lumină şi exult. Ştiu că va dura veşnic, perpetuum mobile. Eu sunt, îmi vorbeşte lumina, dar nu prin cuvinte, prin transmisiunea gândului.

Eu sunt: şi înţeleg prin intelect şi pe calea simţirii înţeleg că e domnul şi că sunt înlăuntrul luminii Taborului, că nu numai o văd, ci şi vieţuiesc în mijlocul ei.

Mai presus de orice sunt fericit, fericit, fericit. Sunt şi pricep că sunt şi mi-o şi spun. Şi lumina parcă e mai fumoasă decât lumina şi parcă ea vorbeşte şi-mi spune cine e. Visul mi se pare a dura mult, mult de tot. Fericirea nu numai că durează continuu, dar şi creşte mereu; dacă răul n-are fund, apoi nici binele n-are plafon, cercul de lumină se lăţeşte din ce în ce, iar fericirea, după ce m-a învăluit mătăsos, deodată, schimbă tactica, devine dură, se aruncă, se prăvăleşte asupră-mi ca nişte avalanşe care - antigravitaţional - mă înalţă; iar apoi procedează în alt fel: duios, mă leagănă - şi-n cele din urmă, fără menajamente - mă înlocuieşte. Nu mai sunt. Ba sunt, dar atât de puternic încât nu mă recunosc" $"$.

Scrise cu mult talent literar, rândurile ce descriu extazul mistic $^{10}$ al părintelui Nicolae vin să completeze şirul de mărturii cu privire la experienţele aparte prin care au trecut oameni cu puternică simţire creştină în închisorile comuniste ${ }^{11}$. Părintele Nicolae, botezat de un alt mare mistic contemporan ce a cunoscut universul

${ }^{9}$ Nicolae STEINHARDT, Jurnalul fericirii, p. 103.

${ }^{10}$ Cf. Nicolae Simon, Extazul creştin, Bucureşti, Edit. Antet, 1999, p. 5.

11 Gheorghe CALCiu-DumitreAsA, „Un nevrednic cuvânt înainte, la o carte de mare şi sfântă vrednicie", în Ioan IANOLIDE, Intoarcerea la Hristos - document pentru o lume nouă, ediţia a II-a, Bucureşti, Edit. Bonifaciu, 2012, p. 7. 
concentraţionar, respectiv Mina Dobzeu ${ }^{12}$, cunoaşte ce înseamnă o astfel de viziune şi se teme de o eventuală înşelare. De aceea, înrădăcinat în frumoasa tradiţie a maieuticii creștine, va mărturisi părintelui Haralambie, coleg de celulă cu el care, asemenea duhovnicului părintelui Siluan ${ }^{13}$, va fi uimit de darurile de care fusese acesta învrednicit. Întrucât se afla însă pe patul morţii şi ajunsese la o înaltă măsură duhovnicească, acesta nu-i va spune ceea ce crede, aşa cum o va face duhovnicul Sfântului rus din spaţiul atonit, fapt ce-l va duce pe acesta la o ulterioară cădere, ci se va comporta în mod firesc, scutindu-l astfel pe fericitul beneficiar al viziunii de o iminentă cădere ${ }^{14}$. Sfaturile părintelui Haralambie, ca şi celelalte îl vor ajuta pe părintele Nicolae ca, asemenea unui alt maramureşean cu care va intra în dialog în repetate rânduri ${ }^{15}$, să nu se teamă de vise, ci să-şi dezvolte acel simţ al „discernământului”, extrem de important după cum se vede din investigarea textelor din tradiţia patristică ${ }^{16}$.

12 Care, la rândul lui va scrie un volum dedicat părintelui Nicolae. Cf.: Mina DobZeu, Amintiri despre N. Steinhardt, Bucureşti, Edit. Lucretius, 2002. Cf. Iurie RoşcA, Părintele Mina Dobzeu, botezătorul lui Nicolae Steinhardt, Chişinău, „Prag-3”, 1997.

${ }^{13}$ Maxim EGGER, Să ne rugăm 15 zile cu Sfântul Siluan, trad. Dora Mezdrea, ediţia a II-a, București, Edit. Sophia, 2010, p. 18; Michel EvdokiMov, „Sfânta Tereza de Lisieux şi Sfântul Siluan Athonitul: doi sfinţi pentru timpurile noastre", în *** „Fratele nostru este viaţa noastră”. Spiritualitatea Cuviosului Siluan Athonitul, trad. Efrosenia Galuşca şi Zaharia-Ciprian Brat, Cluj-Napoca, Edit. Renaşterea, 2016, p. 430.

14 „Părintele Haralambie mă ascultă cu atenţie, nu ascultă, nu tresare. Apoi se pronunţă: nu crede că visele ori arătările sunt suspecte. Dimpotrivă, mă fericeşte. Îmi cere însă multă discreţie şi smerită stăpânire de sine. Şi mai ales e greu de priceput, zice, totuşi, mă roagă să fac un efort - să le iau drept fireşti, drept ceva ne-excepţional, care să nu mă scoată din făgaşul cât se poate de comun al vieţii de obşte. Un gând bun din partea memei, aşa ca o salutare: Iar mila Domnului e bogată; când trece, se întâmplă ca poala hainei Lui să atingă pe te miri cine", Nicolae STEINHARDT, Jurnalul fericirii, p. 103.

${ }^{15}$ Este vorba despre Arhiepiscopul Justinian Chira al Maramureşului. Cf. Justinian CHIRA, Reflecţii III. Din caietele Arhiepiscopului Justinian, Baia Mare, Edit. Episcopiei Ortodoxe a Maramureşului şi Sătmarului, 2016, p. 41-42.

${ }^{16}$ Cf. Thomas SpIDLik, La Spiritualite de l'Orient Chretien, vol. 2 - „La priere”, col. „Orientalia Christiana analecta”, vol. 230, Roma, Pontificio Institutum Studiorum Orientalium, 1988, p. 125. 
Între aspectele ce definesc urcuşul duhovnicesc se numără şi iertarea vrăjmaşilor. Părintele Steinhardt ajunge la acesta, însă reuşeşte să treacă şi la o fază superioară, respectiv găsirea de justificări pentru actele acestora ${ }^{17}$. Dragostea este cea care defineşte percepția lui despre Dumnezeu. Acest lucru explică de ce îl consideră „,boier” în predicile sale ${ }^{18}$. Un text-meditaţie, inserat în discontinuele cronici şi pornind de la experienţa din luna februarie a anului 1962, petrecută la Jilava, este ilustrativ în acest sens:

„E oricând gata să vină în ajutor, atâta aşteaptă. Îi e milă. Pe văduva din Nain, pe orbi, pe femeia gârbovă, îi milostiveşte fără ca ei să fi cerut ceva. Ştie să-şi gradeze aprecierea, dă fiecăruia ce-i al său. Hananeencei care i-a dat dovadă de stăruinţă şi curaj îi spune mai mult decât altora pe care-i izbăveşte, întrebuinţează o formulă complementară: $\mathrm{O}$, femeie mare îţi este credinţa. (Numai ei; numai ei şi exclamativul O! şi calificativul mare).

E mereu - şi cu osebire de grijuliu asupra acestui punct atent şi politicos - prietene îi spune lui Iuda. Niciodată o insultă ori o vorbă dispreţuitoare faţă de păcătos. Nu se vede din niciun text vreun moralism înţepat, vreo pudoare de comandă. Şi nici o condiţie prealabilă pusă păcătoşilor, nici o discriminare" $" 19$.

Note de mare densitate, alcătuite asemenea meditaţiilor lui Dag Hammarsjkold ${ }^{20}$, pot fi de asemenea regăsite în însemnările

17 Astfel, de exemplu, descrie un moment de la Malmaison, în care încearcă să-şi dezvinovățească gardianul, luând întreaga vinovăţie asupra sa: „Când se opreşte caraliul în faţa uşii, reuşesc să ridic (foarte puţin) ochelarii negri; folosesc mâna de care el nu mă ţine strâns. N-are nici o importanţă dacă ştii sau nu în care celulă eşti repartizat, dar simt că orice reţinut sau deţinut îşi face un punct de onoare din a cunoaşte acest amănunt. Caraliul mă surprinde şi mă loveşte cu asprime. E corect: formele trebuie respectate - forma e garanţia dreptului -, ne facem datoria fiecare, suntem chit", Nicolae STEINHARDT, Jurnalul fericirii, p. 107.

18 Ibidem, p. 134; IDEM, Dăruind vei dobândi, p. 170.

${ }^{19}$ IDEM, Jurnalul fericirii, p. 109-110.

${ }^{20}$ Pentru mai multe informaţii cu privire la acesta şi autobiografia sa spirituală, a se vedea şi: Bernhard ERling, A Reader's Guide to Dag Hammarskjöld's 
părintelui Nicolae. E atipică şi extrem de interesantă alăturarea unei meditaţii cu un profund conţinut mistic cu repere de timp şi spaţiu, fapt pe care doar autori precum John Wesley, provenind din tradiţii creştine destul de diferite de cea ortodoxă, 1-au mai făcut ${ }^{21}$. Este vorba despre o însemnare privitoare la cele petrecute în luna martie a anului 1960, în celula cu numărul 18 din cadrul închisorii de tranziţie, Jilava. Iată ce spune el:

„Din câte ştiu toţi aici, din câte aud, din câte se citează, nimic nu cred că poate sta alături de «Nici eu nu te osândesc», de «Mare e credinţa ta, femeie», de «Cred, Doamne, ajută necredinţei mele». Fiecare e de ajuns pentru a mărturisi caracterul supraomenesc al Evangheliilor; din fiecare fenomen ce contribuie la alcătuirea acestor fraze strigă divinul”'22.

Frazele din care ,strigă” divinul îl vor determina pe juristul Nicu Aureliu să descopere creştinismul în momente nu tocmai fericite ale vieţii sale, într-un context care a generat, între altele şi crearea unei adevărate generaţii a sfinţeniei ${ }^{23}$. Faptul că în rândul deţinuţilor au fost şi personalităţi de-a dreptul harismatice ${ }^{24}$, de la care ceilalţi au avut ce învăţa, a fost extraordinar. Aşa s-a întâmplat şi în cazul lui. Convertirea, urmată de catehizarea scurtă şi de „botezul ecumenic”, a fost de asemenea acompaniată de o serie de

Waymarks, St. Peter, Minnesota, 2010; Dag HAMmARSKJöLD, Markings, London, Faber and Faber, 1972; Maxim (Iuliu-Marius) MoRARIU, Autobiografia spirituală a lui Dag Hammarskjöld - o abordare teologică, col. „Theologia”, Cluj-Napoca, Edit. Argonaut, 2016.

21 John Wesley, The Journal of the Rev. John Wesley, A. M., edited by W. Reignald Ward and Richard P. Heitzenrater, col. „Bicentennial Edition of the Works of John Wesley", vol. 18, Abingdon, Abingdon Press, 1988, p. 123.

${ }^{22}$ Nicolae STEINHARDT, Jurnalul fericirii, p. 199.

${ }^{23}$ Cf. Danion VAsile (coord.), Din temniţe spre sinaxare, Galaţi, Edit. Egumeniţa, 2008; Bogdan Munteanu, „Valeriu Gafencu şi Ioan Ianolide. Despre duhul «sfinţilor închisorilor» (II)", în rev. Rost online, 10 februarie 2016, disponibilă şi la adresa: http://www.rostonline.ro/2016/02/valeriu-gafencu-si-ioan-ianolide-despreduhul-sfintilor-inchisorilor-ii/, accesat 21. 02. 2017.

24 *** Viaţa Părintelui Gheorghe Calciu după mărturiile sale şi ale altora, p. 42. 
stări şi trăiri intense, de adevărate momente de euforie. Ele nu se vor estompa odată cu ieşirea din închisoare, ci se vor metamorfoza, vor căpăta contur şi formă, odată ce părintele Nicolae va îmbrăca haina monahală, fapt ce se va repercuta asupra modului său de a fi şi chiar şi a scrisului său²5. Impresia pe care a lăsat-o însă asupra lui această euforie următoare stării baptismale, îl va însoţi multă vreme după eliberare, fapt ce se poate vedea şi din însemnarea dedicată ei (de această dată nedatată, având doar indicele de loc, Jilava):

„Nu te lasă grijile să dormi sau te deşteaptă din somn. Dar se întâmplă ca şi de pe urma fericirii să te pomeneşti treaz în toiul nopţii. Aşa mi s-a întâmplat mult timp după ce am fost primit botezul. Doar din bucurie - out of sheer joy, aus lauter Freude - deschideam brusc ochii, cuprins de o stare euforică, izvoditoare nu de adormire - ca la stupefiante - ci de veghe, de viaţă supraintensă; de somn îmi ardea mie? de odihnă? de oblivon ori evadare? $\mathrm{Nu}$, de prea plin îmi venea să mă reped jos din pat ori de pe prici, să alerg, să strig de bucurie, să-i zgâlţâi şi pe ceilalţi, să le spun cât sunt de fericit, să-i rog să-şi dea seama ce comoară posedă cu toţii, ce sobiţă minunată, ce tranchilizant fără prescripţie dau în spectacol. Ceva din felul meu diurn de a fi trădează probabil, măcar în parte, veselia mea lăuntrică; deoarece unora le sunt surprinzător de drag, în timp ce altora le impun o solidă antipatie" 26 .

Trăirea şi mărturisirea sa creştină ${ }^{27}$ generatoare de stări de extaz şi bucurie, extrem de similare cu cele ale altor mistici precum

${ }^{25}$ De altfel, acesta nu este un lucru singular, mulţi alţi scriitori trecând prin adevărate metamorfoze ale scriiturii odată cu primirea Tainei hirotoniei. Între ei se numără şi faimosul Virgil Gheorghiu. Pentru mai multe informaţii cu privire la acest aspect, a se vedea volumul autobiografic Omul care călătorea singur. Cf. Virgil GHeORghiU, Omul care călătorea singur, trad. Gheorghiţă Ciocioi, Bucureşti, Edit. Sofia, 2010; Thierry Gillyboeuf, Virgil Gheorghiu, scriitorul calomniat, trad. Maxim Morariu, Bucureşti, Edit. Sofia, 2019.

${ }^{26}$ Nicolae STEINHARDT, Jurnalul fericirii, p. 213.

27 Cf. Ştefan ILOAIE, „Trăire şi mărturisire creştină în eseurile teologice ale părintelui Nicolae Delarohia", în Nicolae StEINHARDT, Dăruind vei dobândi. 
Maria Faustina Kowalska ${ }^{28}$, sunt adesea acompaniate de gânduri felurite. Uneori părintele Nicolae se gândeşte cu groază la aspecte de psihologia mulţimilor ${ }^{29}$, comparând elementele de religiozitate cu cele ce privesc guvernarea şi dominaţia ${ }^{30}$. Alteori ţine să vorbească despre puterea eliberatoare a iubirii. Aşa face, de exemplu, într-o notă dedicată anului 1964 şi semnificaţiei lui, mărturisindu-şi crezul cu privire la semnificaţia experienţei carcerale pentru el:

„Cred aşa: că dacă din închisoare pleci şi de pe urma suferinţei te alegi cu dorinţe de răzbunare şi cu sentimente de acreală, închisoarea şi suferinţele au fost de haram. Iar dacă rezultatul e un complex de linişte şi înţelegere şi de scârbă faţă de orice silnicie şi şmecherie, înseamnă că suferinţele şi închisoarea au fost spre folos şi ţin de căile nepătrunse pe care-i place Domnului a umbla.

Puterea de a iubi, la ieşirea din închisoare, trebuie să fi crescut în proporţii de necrezut.

Balzac: dragostea care nu creşte zi de zi este o patimă netrebnică.

Cuvinte de credinţă, ed. Ştefan Iloaie, Rohia, Iaşi, Edit. Mănăstirii Rohia, Edit. Polirom, p. 17.

${ }^{28}$ Maria Faustina KowalsKa, Mic jurnal - milostivirea lui Dumnezeu în sufletul meu, trad. Tadeusz Rostworowski SJ, București, Edit. Arhiepiscopiei RomanoCatolice, 2008; Kenneth Di MAGGIO, „Medieval Voices, Modern Mystic: The Continuing Tradition of Female Mystical Writing in the 20th Century Diary of St. Maria Faustina Kowalska", International Journal of Religion \& Spirituality in Society, 5 (2015), no. 4, p. 87.

${ }^{29}$ Cf. Gustave Le Bon, Psihologia mulţimilor, trad. Mariana Tabacu, Bucureşti, Antet XX Press, 2012.

${ }^{30}$ Astfel, de exemplu, el scrie: „De fiecare dată câte unul se ia drept Dumnezeu şi statornicește reguli nouă, de pe câte un munte înalt. Unul sau câţiva (acum situaţionaliştii, după marxişti: altă lume, alte axiome. Şi totul, fireşte la modul absolut). Şi de fiecare dată găsesc o turmă. Vitrinele sunt primenite: alte mărfuri, alte odoare, alte garnituri. Și câtre un intelectual care cunoaşte bucuria inefabilă de a fi Profet. (Se înnoiesc - lesne de-nțeles - nu numai zorzoanele din vitrine, ci şi inventarul din pivniţă: se ascut alte cuţite, se ung alte pistoale, se şapiografiază alte manifeste)", Nicolae STEINHARDT, Jurnalul fericirii, p. 360. 
Desigur că n-am suferit îndeajuns ca să am acele îngăduitoare maniere şi acea tandreţe neclintită pe care le obţinem numai după crunte înşelătorii şi reiterate călcări în picioare" ${ }^{\prime 31}$.

Gândurile sale, pline de tensiune şi tristeţe uneori, subliniază, ca şi cele ale unor suferinzi precum Nicolae Purcărea ${ }^{32}$, un aspect esenţial, acela că Dumnezeu este factorul comun al umanităţii. El este Cel care-i poate face pe oameni să se tolereze, iubească şi chiar să coexiste ${ }^{33}$. Alături de aceste reflecţii şi altele, cu conţinut patriotic ${ }^{34}$, se găsesc şi descrieri, străbătute de ample referinţe la autori clasici din literatură sau filosofie, ce vin parcă să consfinţească statutul de caracter enciclopedic al autorului lor şi să transforme notele sale într-un text ce-l invită pe cititor să pătrundă în lumea lecturii.

\section{Concluzii}

După cum am încercat să arătăm în paginile cercetării de faţă, Jurnalul fericirii reprezintă un text fundamental pentru cultura

${ }^{31}$ Ibidem, p. 270.

32 Cf. Nicolae PurcăreA, Urlă haita... - Piteşti, Canal, Gherla, Jilava, Aiud, Bucureşti, Fundaţia Sfinţii Închisorilor, 2012, p. 285.

33 „Factorul comun al oamenilor poate fi numai Dumnezeu, numai prin El ne putem reciproc tolera şi încerca să ne iubim. În lipsa acestui catalizator, reacţiile rămân de respingere şi indiferenţă. Laplace credea că se poate lipsi de această ipoteză, dar progresul ştiinţific 1-a determinat pe Werner Heisenberg să ceară sprijinul filosofiei, iar lumea de rând s-a convins că are nevoie de acest ocol pentru a nu se preface în ţarc de animale, ori în casă de nebuni”, Nicolae STEINHARDT, Jurnalul fericirii, p. 258.

34 „Poporul român e înzestrat cu o putere transfiguratoare ce-i permite să preschimbe întregul univers şi să pătrundă în cosmosul liturgic (să participe la celebrarea liturghiei cosmice ar spune Maxim Mărturisitorul). Împotriva soartei nu te poţi apăra ca împotriva unor vrăjmaşi; nu poţi decât să dai un înţeles nou consecinţelor ineluctabile ale destinului în curs de împlinire. $\mathrm{Nu}$-i vorba de fatalism, de vreme ce fatalistul nici nu cred că poate preface semnificaţia ursitei”, Ibidem, p. 265. Cf. Justinian CHIRA, Reflecţii III. Din caietele Arhiepiscopului Justinian, Baia Mare, Edit. Episcopiei Ortodoxe a Maramureşului şi Sătmarului, 2016, p. 34. 
română în general şi pentru spaţiul teologic în particular. Ba mai mult, a trecut graniţa ţării noastre, transformându-1 pe părintele Nicolae Steinhardt într-un scriitor intens citit, ce aduce o mărturie preţioasă cu privire la fenomenul concentraţionar din România comunistă, şi urmările lui. În acelaşi timp, însemnările sale sunt şi un frumos text autobiografic. Autorul vorbeşte despre sine, referindu-se la experienţele pe care le-a trăit, pe care le vede adesea prin prisma stării sufleteşti sau comparându-le cu unele ale unor scriitori de seamă, îşi monitorizează starea sufletească şi încearcă să se împace cu sine şi cu alții. În cazul lui, scrisul are valențe de-a dreptul eliberatoare, putând fi utilitzat cu certitudine în arealul psihologic.

Din perspectiva autobiografiei spirituale, textul pe care îl avem în vedere este, deși nu poate fi subsumat întru totul genului, din motive anterior prezentate, o preţioasă creaţie. Pasajele ce ţin de experienţa transfiguratoare ce precede, acompaniază sau succede convertirea scriitorului, sunt frumoase şi plăcute lecturii. În plus, au o valoare practică aparte, atât datorită densului lor conţinut empatic, cât şi din pricina faptului că pot oferi soluţii la anumite probleme, sau pot fi utile cititorului la depăşirea unor stări sufleteşti de-a dreptul blocante. Din perspectivă duhovnicească, ele sintetizează tradiţia patristică a Bisericii Răsăritene, fiind întru totul pe linia ei. Reuşesc însă să o coreleze şi cu gânditori din circuitul larg al unei gândiri pe care cercetarea de astăzi ar defini-o drept secularizată sau laică, reliefând faptul că principiile ce stau la baza gândirii unor autori reprezentativi ai ei sunt creştine. Revendicându-o cultura laică, cu alte cuvinte.

Pentru toate acestea, dar şi pentru multe alte aspecte, considerăm că lucrarea pe care am încercat să o prezentăm în paginile cercetării de faţă se constituie într-o frumoasă contribuţie românească la dezvoltarea acestui gen, reliefând deschiderea Ortodoxiei de pe aceste meleaguri înspre descoperirea sinelui şi crearea de punţi de dialog la nivel inter-disciplinar şi ecumenic. 


\section{Bibliografie}

1. *** Viaţa Părintelui Gheorghe Calciu după mărturiile sale şi ale altora, ediţie îngrijită la Mănăstirea Diaconeşti, Bucureşti, Edit. Christiana, 2007.

2. ANANIA, Valeriu, Memorii, Iaşi, Edit. Polirom, 2008.

3. ANDRONESCU, Demostene, Reeducarea de la Aiud. O radiografie memorialistică, Piteşti, Edit. Manuscris, 2018.

4. Calciu-Dumitreasa, Gheorghe, Cuvinte vii - „a sluji lui Hristos înseamnă suferinţă!", Bacău, Edit. Bonifaciu, 2009.

5. CHIRA, Justinian, Reflecţii III. Din caietele Arhiepiscopului Justinian, Baia Mare, Edit. Episcopiei Ortodoxe a Maramureşului şi Sătmarului, 2016.

6. CONSTANTE, Lena , Evadarea imposibilă - penitenciarul politic de femei, Miercurea Ciиc (1957-1961), ediţia a 2-a, Bucureşti, Edit. Florile Dalbe, 1996.

7. IDEM, Evadarea tăcută -3000 de zile singură în închisorile din România, Bucureşti, Edit. Humanitas, 1992.

8. DobZEU, Mina, Amintiri despre N. Steinhardt, Bucureşti, Edit. Lucretius, 2002.

9. EGGER, Maxim, Să ne rugăm 15 zile cu Sfântul Siluan, trad. Dora Mezdrea, ediţia a II-a, Bucureşti, Edit. Sophia, 2010.

10. ERLING, Bernhard, A Reader's Guide to Dag Hammarskjöld's Waymarks, St. Peter, Minnesota, 2010.

11. EvDOKIMOV, Michel, „Sfânta Tereza de Lisieux şi Sfântul Siluan Athonitul: doi sfinţi pentru timpurile noastre", în *** „Fratele nostru este viaţa noastră”. Spiritualitatea Cuviosului Siluan Athonitul, trad. Efrosenia Galuşca şi Zaharia-Ciprian Brat, Cluj-Napoca, Edit. Renaşterea, 2016.

12. GHEORGHIU, Virgil, Omul care călătorea singur, trad. Gheorghiţă Ciocioi, Bucureşti, Edit. Sofia, 2010.

13. GILlyBOEUF, Thierry, Virgil Gheorghiu, scriitorul calomniat, trad. Maxim Morariu, Bucureşti, Edit. Sofia, 2019.

14. Grossu, Nicole-Valery , Bénie sois-tu, prison, Paris, Les Editions du Plon, 1978. 
Nicolae Steinhardt - o contribuție românească la autobiografia spirituală

15. HAMMARSKJÖLD, Dag, Markings, London, Faber and Faber, 1972.

16. IANOLIDE, Ioan, Intoarcerea la Hristos - document pentru o lume nouă, ediţia a II-a, Bucureşti, Edit. Bonifaciu, 2012.

17. IDEM, Deţinutul profet, ediţie îngrijită de Mănăstirea Diaconeşti, Bucureşti, Edit. Bonifaciu, 2009.

18. ILOAIE, Ştefan, „Trăire şi mărturisire creştină în eseurile teologice ale părintelui Nicolae Delarohia", în

19. KowalsKA, Maria Faustina , Mic jurnal - milostivirea lui Dumnezeu în sufletul meu, trad. Tadeusz Rostworowski SJ, Bucureşti, Edit. Arhiepiscopiei Romano-Catolice, 2008.

20. Le BON, Gustave, Psihologia multimilor, trad. Mariana Tabacu, Bucureşti, Antet XX Press, 2012.

21. MagGIO, Kenneth Di, „Medieval Voices, Modern Mystic: The Continuing Tradition of Female Mystical Writing in the 20th Century Diary of St. Maria Faustina Kowalska”, International Journal of Religion \& Spirituality in Society, 5 (2015), no. 4.

22. MORARIU, Iuliu-Marius / Ştefan JOSAN, „Elements of spiritual autobiography in the literary works of Virgil Gheorghiu", în Research and Science Today, 6 (2016), no. 1 (11), p. 83-88.

23. MORARIU, Iuliu-Marius, „An interdisciplinary genre in the Theological Literature: the spiritual autobiography and its landmarks for the Orthodox space", in Journal of Education, Culture and Society, VII (2018), no. 1, p. 145-149.

24. MORARIU, Maxim, „Saint Silouane l'Athonite el l'autobiographie spirituelle dans l'Eglise Orthodoxe", în Presence d'En Calcat, 55 (2016), no. 1, p. 35-39. MORARIU, Maxim (Iuliu-Marius), Autobiografia spirituală a lui Dag Hammarskjöld: o abordare teologică, Cluj-Napoca, Edit. Argonaut, 2016.

25. MIDEM, „Aspects of Applied Ethics in the Spiritual Autobiographies from the Orthodox Space in the 19thand 20th Centuries", în Camelia IGNĂTESCU, Antonio SANDU, Tomiţă CIULEI (eds.), Proceedings Volume: Rethinking Social Action. Core Values in Practice, Iași, Londra, Edit. Lumen, 2017, p. 548-557. 
26. IDEM, „Aspects of political theology in the spiritual autobiographies of the Orthodox space? New potential keys of lecture", în Astra Salvensis, V (2017), no. 10, p. 128-133.

27. IDEM, „Aspects of political theology in the spiritual autobiography of Dag Hammarskjöld", în HTS Teologiese Studies / Theological Studies, 74 (2018), no. 4, a4857, 2018, p. $1-5$.

28. IDEM, „Aspects of political theology in the spiritual autobiography of Saint John of Kronstadt (1829-1908)", în HTS Teologiese Studies / Theological Studies, 74 (2018), no. 4, 4993, 2018, p. 1-5.

29. IDEM, „Educational aspects in the spiritual autobiography from the Orthodox space of the 19th and 20th centuries", în Ion Albulescu, Adriana-Denisa MANEA, Iuliu-Marius MoRARIU, Education, Religion, Family in Contemporary Society Proceedings of the Conference, Saarbrucken, Lambert Academic Publishing, 2017, p. 113-123.

30. IDEM, ,The spiritual autobiography in the Eastern space in the second half of the XIXth and XXth centuries", în Astra Salvensis, III (2015), Supplement no 1 - „New Approaches in Contemporary Theology", p. 166-174.

31. IDEM, Repere ale autobiografiei spirituale din spaţiul ortodox in secolele XIX şi XX: Ioan de Kronstadt, Siluan Athonitul şi Nicolae Berdiaev, Iassy, Lumen Press, 2019.

32. Munteanu, Bogdan, „Valeriu Gafencu şi Ioan Ianolide. Despre duhul «sfinţilor închisorilor» (II)", în rev. Rost online, 10 februarie 2016, disponibilă şi la adresa: http://www.rostonline.ro/2016/02/valeriu-gafencu-si-ioanianolide-despre-duhul-sfintilor-inchisorilor-ii/, accesat 21. 02. 2017.

33. NICHIFOR, Nichifor, Memorii, vol. 2 - „Pribeag în ţara mea răspuns la actul meu de acuzare - mărturii din închisoare”, ed. Alexandru Condeescu, Bucureşti, Edit. Muzeului Literaturii Române, 1996.

34. OȚEl Petrescu, Aspazia , Cu Hristos în celulă, ediţia a 2-a, Bucureşti, Edit. Areopag, 2012. 
Nicolae Steinhardt - o contribuție românească la autobiografia spirituală

35. PURCĂREA, Nicolae, Urlă haita... - Piteşti, Canal, Gherla, Jilava, Aiud, Bucureşti, Fundaţia Sfinţii Închisorilor, 2012.

36. RĂDULEANU, Galina , Repetiţie la moarte, col. „Din spatele gratiilor”, Piteşti, Edit. Fundaţiei Sfinţii Închisorilor, 2013.

37. RoșCA, Iurie, Părintele Mina Dobzeu, botezătorul lui Nicolae Steinhardt, Chişinău, „Prag-3”, 1997.

38. Sfânta TEREZA DIN AVILA, Castelul interior, trad. Christian Tămaş, Iaşi, Edit. Ars Longa, 1995.

39. SIMON, Nicolae, Extazul creştin, Bucureşti, Edit. Antet, 1999.

40. SPIDLIK, Thomas, La Spiritualite de l'Orient Chretien, vol. 2 „La priere”, col. „Orientalia Christiana analecta”, vol. 230, Roma, Pontificio Institutum Studiorum Orientalium, 1988.

41. IDEM, Jurnalul fericirii, Rohia, Edit. Mănăstirii Rohia, 2005.

42. State, Aurel , Drumul crucii. Amintiri de pe front şi din Gulaguri, Piteşti, Bucureşti, Edit. Rost, Edit. Fundaţiei Inchisorilor, 2013.

43. STEINHARDT, Nicolae, Călătoria unui fiu risipitor - roman, ed. Ioan Pintea, Bucureşti, Edit. Adonai, 1995.

44.STEINHARDT, Nicolae, Dăruind vei dobândi, Rohia, Edit. Mănăstirii Rohia, 2006.

45. IDEM, Cartea împărtăşirii, ed. Ion Vârtic, Cluj-Napoca, Edit. Biblioteca Apostrof, 1998.

46. IDEM, Critică la persoana I, Cluj-Napoca, Editura Dacia, 2001. 47. IDEM, Cuvinte de credinţă, ediţie definitivă îngrijită de Ioan Pintea, Bucureşti, Edit. Humanitas, 2006; IDEM, Drumul către isihie - inedite, eseuri, ed. Oana Cătina, Cluj-Napoca, Edit. Dacia, 1999.

48. IDEM, Dumnezeu în care spui că nu crezi... Scrisori către Virgil Ierunca (1967-1983), ed. Monica Manu, Bucureşti, Edit. Humanitas, 2000.

49. IDEM, Escale în timp şi spaţiu sau dincoace şi dincolo de texte, Bucureşti, Edit. Cartea Românească, 1987.

50. IDEM, Eu însumi şi alţi câțiva (eseuri noi şi vechi), ed. Ioan Pintea, Cluj-Napoca, Edit. Dacia, 2001.

51. IDEM, Ispita lecturii, ed. Ioan Pintea, Cluj-Napoca, Edit. Dacia, 2000. 
52. IDEM, În genul...tinerilor, Bucureşti, Edit. Cultura Poporului, 1934.

53. IDEM, Monologul polifonic, ed. Virgil Bulat, Cluj-Napoca, Edit. Dacia, 1991.

54. IDEM, Intre viaţă şi cărţi, Bucureşti, Edit. Cartea Românească, 1976.

55. VASILE, Danion (coord.), Din temniţe spre sinaxare, Galaţi, Edit. Egumeniţa, 2008.

56. WESLEY, John, The Journal of the Rev. John Wesley, A. M., edited by W. Reignald Ward and Richard P. Heitzenrater, col. „Bicentennial Edition of the Works of John Wesley”, vol. 18, Abingdon, Abingdon Press, 1988. 